\title{
Saccharopolyspora tripterygii sp. nov., an endophytic actinomycete isolated from the stem of Tripterygium hypoglaucum
}

\author{
Correspondence \\ Wen-Jun Li \\ wjli@ynu.edu.cn or \\ liact@hotmail.com
}

\author{
Jie Li, ${ }^{1}$ Guo-Zhen Zhao, ${ }^{1}$ Sheng Qin, ${ }^{1}$ Hai-Yu Huang, ${ }^{1}$ Wen-Yong Zhu, ${ }^{1}$ \\ $\mathrm{Li}-\mathrm{Hua} \mathrm{Xu}^{1}$ and Wen-Jun $\mathrm{Li}^{1,2}$
${ }^{1}$ The Key Laboratory for Microbial Resources of the Ministry of Education, PR China, and Laboratory for Conservation and Utilization of Bio-Resources, Yunnan Institute of Microbiology, Yunnan University, Kunming, 650091, PR China Chinese Academy of Sciences, Guangzhou, 510301, PR China \\ ${ }^{2}$ Guangdong Key Laboratory of Marine Materia Medica, South China Sea Institute of Oceanology,
}

\begin{abstract}
An endophytic actinomycete, designated strain YIM $65359^{\top}$, was isolated from a surfacesterilized stem sample of Tripterygium hypoglaucum collected from Yunnan province, south-west China. The morphological and chemotaxonomic properties of the new isolate were consistent with those of members of the genus Saccharopolyspora. Analysis of 16S rRNA gene sequences revealed that the new isolate was most closely related to 'Saccharopolyspora endophytica' YIM 61095 (98.6\%), Saccharopolyspora flava AS4.1520 ${ }^{\top}$ (97.6\%) and Saccharopolyspora spinosa DSM $44228^{\top}(97.0 \%)$. The results of DNA-DNA hybridizations $(57.5 \%, 44.9 \%$ and $48.5 \%$, respectively) with the above micro-organisms, in combination with differences in the biochemical and physiological characteristics, suggested that strain YIM $65359^{\top}$ should be classified as a novel species of the genus Saccharopolyspora. The name Saccharopolyspora tripterygii sp. nov.

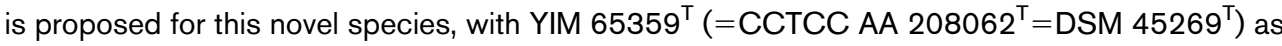
the type strain.
\end{abstract}

The genus Saccharopolyspora was proposed in 1975 by Lacey \& Goodfellow (1975) to describe actinomycetes from sugar cane bagasse which grew at $40{ }^{\circ} \mathrm{C}$ and produced white aerial mycelia with bead-like chains of spores enclosed in a characteristic hairy sheath. Members of this genus are aerobic, Gram-positive, non-acid-fast organisms with substrate hyphae that either fragment into rod-shaped elements, do not fragment or are partially transformed into chains of spores (Korn-Wendisch et al., 1989). They lack mycolic acids, but contain meso-diaminopimelic acid, arabinose and galactose in the cell wall and possess predominantly tetrahydrogenated menaquinones with nine isoprene units (Embley et al., 1987; Goodfellow et al., 1989). The DNA G+C contents of members of the genus are in the range $66-77 \mathrm{~mol} \%$ (Goodfellow et al., 1989). In this study, we describe the phenotypic and genotypic properties of a novel species of the genus Saccharopolyspora.

Strain YIM $65359^{\mathrm{T}}$ was isolated during a search for endophytic microbes from pharmaceutical plants with

The GenBank/EMBL/DDBJ accession number for the 16S rRNA gene sequence of strain YIM 65359 ${ }^{\top}$ is FJ214364.

A detailed fatty acid composition for strain YIM $65359^{\top}$ is presented in Supplementary Table S1, available with the online version of this paper. the prospect that they might produce novel bioactive products. The novel strain was isolated from the surfacesterilized stem of samples of Tripterygium hypoglaucum, which were collected from Yunnan province, south-west China. The isolation procedures were performed as described by Li et al. (2009). The purified strain was routinely cultured on YIM 38 medium [ $4 \mathrm{~g}$ malt extract, 4 g yeast extract, $4 \mathrm{~g}$ glucose, vitamin mixture $(0.5 \mathrm{mg}$ each of thiamine- $\mathrm{HCl}$, riboflavin, niacin, pyridoxine- $\mathrm{HCl}$, inositol, calcium pantothenate and $p$-aminobenzoic acid and $0.25 \mathrm{mg}$ biotin), $20 \mathrm{~g}$ agar; $\mathrm{pH} 7.2$ ] at $28{ }^{\circ} \mathrm{C}$ and stored as glycerol suspension $(20 \%, \mathrm{v} / \mathrm{v})$ at $-70{ }^{\circ} \mathrm{C}$.

Cultural characteristics were observed on yeast extractmalt extract agar (ISP 2), oatmeal agar (ISP 3), inorganic salts-starch agar (ISP 4), glycerol-asparagine agar (ISP 5) (Shirling \& Gottlieb, 1966), Czapek's agar, potato agar and nutrient agar (Waksman, 1961) media following growth at $28{ }^{\circ} \mathrm{C}$ after $7,14,21$ and 28 days. Colour determination was performed by using colour chips from the ISCC-NBS colour charts (standard samples, no. 2106) (Kelly, 1964). Morphological properties were examined using a light microscope (BH-2; Olympus) and a scanning electron microscope (JSM 5600LV; JEOL) after 20-30 days incubation on YIM 38 medium at $28{ }^{\circ} \mathrm{C}$. 
Physiological tests such as growth at different temperatures $\left(4,10,15,20,28,37,45,55\right.$ and $\left.65{ }^{\circ} \mathrm{C}\right), \mathrm{pH}$ values $(4.0$ $10.0)$ and $\mathrm{NaCl}$ concentrations $[1,3,5,7,10,12,15$ and $20 \%(\mathrm{w} / \mathrm{v})$ ] were examined by growing the novel strain on YIM 38 medium as the basal medium. Hydrolysis of starch, gelatin and Tweens 20, 40 and 80 was determined as described by Smibert \& Krieg (1994). Carbon source utilization tests and other phenotypic characteristics were conducted using the media and methods of Gordon et al. (1974).

Strain YIM $65359^{\mathrm{T}}$ grew well on ISP 2, ISP 4, ISP 5 and potato agar media, with moderate growth on ISP 3 , Czapek's agar and nutrient agar media. White aerial mycelia developed well on most of the media tested. The vegetative mycelia were well developed and soft orangeyellow to moderate orange-yellow in colour on all media tested. Soluble pigments were not produced on any of the media. Strain YIM $65359^{\mathrm{T}}$ exhibited morphological properties characteristic of members of the genus Saccharopolyspora, forming extensively branched substrate mycelia that did not fragment and aerial mycelia developed well with long spore chains. All spores were non-motile and smooth-surfaced (Fig. 1). Detailed physiological results are given in Table 1 and in the species description.

The cellular fatty acid composition was determined as described by Sasser (1990), using the Microbial Identification System (MIDI). For other chemotaxonomic analysis, freeze-dried cells were obtained from cultures grown in YIM 38 broth for 1 week at $28{ }^{\circ} \mathrm{C}$. The isomer of diaminopimelic acid and the sugars of the whole-cell hydrolysates were determined using TLC as described by Staneck \& Roberts (1974). Phospholipids were identified according to published procedures (Minnikin et al., 1979; Collins \& Jones, 1980). Menaquinones were extracted (Collins et al., 1977) and separated by HPLC (Tamaoka et al., 1983). The $\mathrm{G}+\mathrm{C}$ content of the genomic DNA was determined by the HPLC method according to Mesbah et al. (1989).

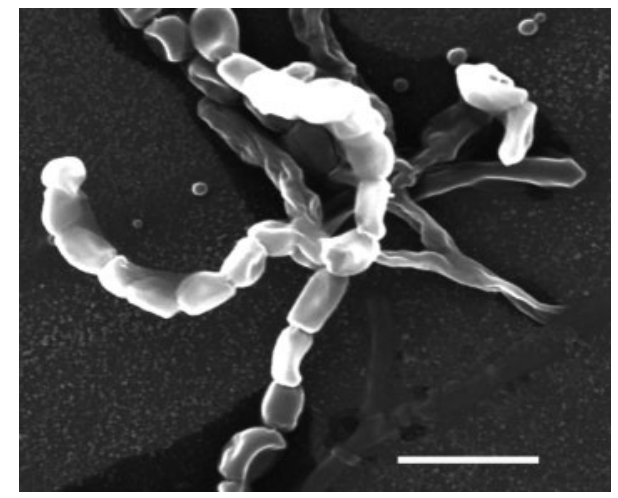

Fig. 1. Scanning electron micrograph of spore chains of strain YIM $65359^{\top}$ after growth on YIM 38 medium at $28{ }^{\circ} \mathrm{C}$ for 28 days. Bar, $2 \mu \mathrm{m}$.
Table 1. Distinguishing characteristics of strain YIM $65359^{\top}$ and the type strains of its closest phylogenetic relatives

Strains: 1, YIM $65359^{\mathrm{T}}$; 2, 'S. endophytica' YIM 61095; 3, S. flava AS4. $1520^{\mathrm{T}} ; 4$, S. spinosa DSM $44228^{\mathrm{T}}$. Data for all species are from the present study unless indicated. + , Positive; -, negative; ND, not determined.

\begin{tabular}{|c|c|c|c|c|}
\hline Characteristic & 1 & 2 & 3 & 4 \\
\hline \multicolumn{5}{|l|}{ Hydrolysis of: } \\
\hline Gelatin & - & - & - & + \\
\hline Urea & + & - & + & + \\
\hline Starch & - & + & + & - \\
\hline Tween 80 & - & + & + & + \\
\hline $\mathrm{H}_{2} \mathrm{~S}$ production & - & - & - & + \\
\hline Nitrate reduction & - & + & + & + \\
\hline $\begin{array}{l}\text { Highest } \mathrm{NaCl} \text { tolerance } \\
(\%, \mathrm{w} / \mathrm{v})\end{array}$ & 12 & 15 & 7 & 12 \\
\hline Growth temperature $\left({ }^{\circ} \mathrm{C}\right)$ & $10-37$ & $20-45$ & $20-37$ & $15-37$ \\
\hline Growth pH & $7.0-8.0$ & $5.0-9.0$ & $7.0-8.0$ & $7.0-8.0$ \\
\hline \multicolumn{5}{|c|}{ Utilization as sole carbon sources: } \\
\hline Aesculin & + & + & + & - \\
\hline D-Arabinose & + & - & - & + \\
\hline Cellobiose & - & + & + & + \\
\hline Dulcitol & - & - & - & + \\
\hline Inositol & - & + & + & + \\
\hline D-Mannose & - & + & - & - \\
\hline L-Rhamnose & - & + & + & + \\
\hline D-Ribose & + & + & - & + \\
\hline Sodium acetate & + & - & + & + \\
\hline Sodium oxalate & - & + & + & - \\
\hline D-Sorbitol & - & + & + & + \\
\hline Sucrose & - & + & + & + \\
\hline \multicolumn{5}{|c|}{ Utilization as sole nitrogen sources: } \\
\hline Adenine & + & + & + & - \\
\hline L-Alanine & - & + & + & + \\
\hline L-Arginine & + & - & - & + \\
\hline Glycine & - & - & + & + \\
\hline L-Tyrosine & + & + & - & + \\
\hline Xanthine & - & + & + & - \\
\hline DNA G + C content $(\mathrm{mol} \%)^{\star}$ & 70.5 & 66.2 & 67.0 & ND \\
\hline
\end{tabular}

${ }^{\star}$ Data from previous studies except for strain YIM $65359^{\mathrm{T}}$ (Mertz \& Yao, 1990; Lu et al., 2001; Qin et al., 2008).

Strain YIM $65359^{\mathrm{T}}$ contained meso-diaminopimelic acid as the diagnostic diamino acid of the cell-wall peptidoglycan. Whole-cell hydrolysates contained arabinose, galactose, glucose and ribose. Diphosphatidylglycerol, phosphatidylglycerol, phosphatidylmethylethanolamine, phosphatidylethanolamine and phosphatidylcholine were the major phospholipids, with moderate amounts of phosphatidylinositol, phosphatidylinositol mannosides and one unknown phospholipid. The predominant menaquinone was MK-9 $\left(\mathrm{H}_{4}\right)(87.5 \%)$ and MK-9 $\left(\mathrm{H}_{2}\right)$ was also detected as a minor component. The fatty acid profile was composed of iso- $\mathrm{C}_{16: 0} \quad(31.29 \%)$, anteiso- $\mathrm{C}_{17: 0}$ $(20.31 \%)$, iso- $\mathrm{C}_{15: 0}(14.70 \%)$, iso- $\mathrm{C}_{17: 0}(10.19 \%), \mathrm{C}_{16: 0}$ 
9 methyl (7.00\%), $\mathrm{C}_{17: 1}$ cis9 (2.96\%), anteiso- $\mathrm{C}_{15: 0}$ $(2.87 \%)$, iso- $\mathrm{C}_{16: 1} \mathrm{H}(2.77 \%), \mathrm{C}_{16: 1}$ cis 9 (1.94\%), iso$\mathrm{C}_{14: 0}(1.73 \%)$, iso- $\mathrm{C}_{13: 0}(0.60 \%), \mathrm{C}_{18: 1}$ cis 9 (0.55\%), $\mathrm{C}_{15: 1}$ B $\quad(0.54 \%), \mathrm{C}_{17: 0} \quad(0.54 \%), \mathrm{C}_{17: 0} 10$ methyl $(0.53 \%), \mathrm{C}_{17: 1}$ anteiso $\mathrm{B} /$ iso I $(0.52 \%), \mathrm{C}_{16: 0}(0.50 \%)$ and anteiso- $\mathrm{C}_{17: 1} \mathrm{C}(0.47 \%)$. A detailed fatty acid profile of the novel strain compared with those of closely related strains is presented in Supplementary Table S1 (available in IJSEM Online). The $\mathrm{G}+\mathrm{C}$ content of the genomic DNA from strain YIM $65359^{\mathrm{T}}$ was $70.5 \mathrm{~mol} \%$.

Genomic DNA extraction, amplification and 16S rRNA gene sequencing were performed as described previously by Li et al. (2007). The resulting 16S rRNA gene sequence was aligned with corresponding sequences of representatives of the genus Saccharopolyspora (retrieved from the GenBank/ EMBL/DDBJ database) using CLUSTAL_X (Thompson et al., 1997). A phylogenetic tree was constructed using the neighbour-joining (Saitou \& Nei, 1987) tree-making algorithm from MEGA version 4.0 (Tamura et al., 2007). The PHYLIP version 3.6 software package was used to construct the maximum-likelihood (Felsenstein, 1981) tree. The topology of the phylogenetic tree was evaluated by the bootstrap resampling method of Felsenstein (1985) with 1000 replicates.

The almost-complete 16S rRNA gene sequence of strain YIM $65359^{\mathrm{T}}(1418 \mathrm{bp})$ was generated. Phylogenetic analysis based on 16S rRNA gene sequences revealed that strain YIM $65359^{\mathrm{T}}$ belonged to the genus Saccharopolyspora (Fig. 2). Highest sequence similarities were found with 'Saccharopolyspora endophytica' YIM 61095 (98.6\%), followed by Saccharopolyspora flava AS4.1520 ${ }^{\mathrm{T}}$ (97.6\%) and Saccharopolyspora spinosa DSM $44228^{\mathrm{T}}$ (97.0\%). Genomic relatedness between strains YIM $65359^{\mathrm{T}}$ and ' $S$. endophytica' YIM 61095, S. flava AS4. $1520^{\mathrm{T}}$ and S. spinosa DSM $44228^{\mathrm{T}}$ was determined by using DNA-DNA hybridization according to the fluorometric micro-well method (Ezaki et al., 1989; He et al., 2005). The experiments were performed with three replications. The levels of DNA-DNA relatedness of strain YIM $65359^{\mathrm{T}}$ to ' $S$. endophytica' YIM 61095, S. flava AS4. $1520^{\mathrm{T}}$ and S. spinosa DSM $44228^{\mathrm{T}}$ were determined to be $57.5 \%$ (mean value, SD $4.5 \%$ ), $44.9 \%$ (mean value, SD $3.5 \%$ ) and $48.5 \%$ (mean value, SD $3.0 \%$ ), respectively. These data supported the finding that strain YIM $65359^{\mathrm{T}}$ represents a separate genomic species.

Besides the genotypic evidence, strain YIM $65359^{\mathrm{T}}$ could also be distinguished from its closest relatives by additional phenotypic characteristics. 'S. endophytica' YIM 61095 produces pink diffusible pigments when grown on ISP 5, Czapek's agar and potato agar media (Qin et al., 2008), while S. spinosa DSM $44228^{\mathrm{T}}$ also produces brown soluble pigments on some media (Mertz \& Yao, 1990), whereas strain YIM $65359^{\mathrm{T}}$ did not produce soluble pigments on any of the media tested. The substrate mycelium of S. flava AS4.1520 ${ }^{\mathrm{T}}$ fragments into rod-shaped elements ( $\mathrm{Lu}$ et al., 2001), but this was not found in strain YIM $65359^{\mathrm{T}}$.

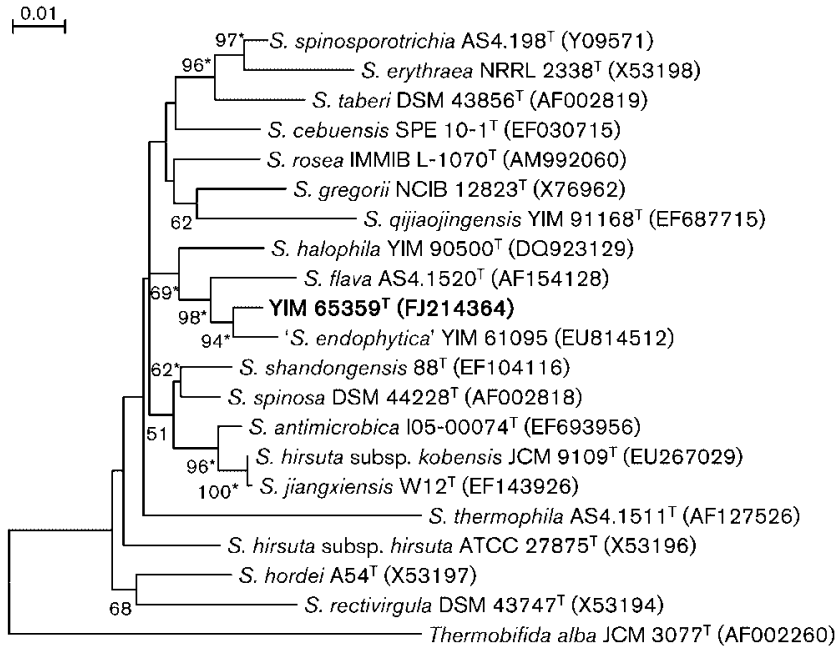

Fig. 2. Neighbour-joining tree based on $16 \mathrm{~S}$ rRNA gene sequences showing the phylogenetic relationship between strain YIM $65359^{\top}$ and other members of the genus Saccharopolyspora. Bootstrap values (expressed as percentages of 1000 replications) $>50 \%$ are given at the nodes. Asterisks indicate the clades that were conserved when the maximum-likelihood method was used to construct the phylogenetic tree. Bar, 1 nt substitution per $100 \mathrm{nt}$.

Furthermore, as shown in Table 1, many differences between strains YIM $65359^{\mathrm{T}}$ and 'S. endophytica' YIM 61095, S. flava AS4.1520 ${ }^{\mathrm{T}}$ and S. spinosa DSM $44228^{\mathrm{T}}$ were detected during the determination of phenotypic properties, such as differences in the hydrolysis of gelatin, urea, starch and Tween 80 , in the production of $\mathrm{H}_{2} \mathrm{~S}$, in nitrate reduction, in the utilization of sole carbon and nitrogen sources, in tolerance to $\mathrm{NaCl}$, in the temperature and $\mathrm{pH}$ value ranges for growth and in the compositions of fatty acids (Table 1 and Supplementary Table S1). On the basis of the data presented in the this study, we suggest that strain YIM $65359^{\mathrm{T}}$ represents a novel species of the genus Saccharopolyspora, for which the name Saccharopolyspora tripterygii sp. nov., is proposed.

\section{Description of Saccharopolyspora tripterygii sp. nov.}

Saccharopolyspora tripterygii (trip.te.ry'gi.i. N.L. n. Tripterygium a botanical genus name; N.L. gen. n. tripterygii of Tripterygium, the plant genus from which this species was isolated).

Forms extensively branched substrate mycelia and aerial mycelia differentiate into long spore chains. Spores are elliptical or short rods $(0.5-0.8 \times 1.0-1.5 \mu \mathrm{m})$. Spore surface is smooth. Aerial mycelia are white, vegetative mycelia are orange-yellow. No soluble pigment is produced. Growth occurs at $10-37{ }^{\circ} \mathrm{C}$ and $\mathrm{pH} 7.0-8.0$. The $\mathrm{NaCl}$ tolerance range is up to $12 \%(\mathrm{w} / \mathrm{v})$. Catalase is produced. Negative for the production of $\mathrm{H}_{2} \mathrm{~S}$ and melanin, for nitrate reduction and for milk coagulation 
and peptonization. Urea and Tweens 20 and 40 are hydrolysed, but Tween 80 , cellulose, gelatin and starch are not hydrolysed. Utilizes D-arabinose, D-fructose, Dgalactose, glucose, D-lactose, maltose, D-mannitol, raffinose, D-ribose, sodium acetate, trisodium citrate and Dxylose as sole carbon sources. Acid is produced from amygdalin and aesculin. Cellobiose, dulcitol, inositol, Dmannose, L-rhamnose, sodium oxalate, D-sorbitol and sucrose are not utilized. Adenine, L-arginine, L-asparagine, L-hydroxyproline, hypoxanthine, L-lysine, L-phenylalanine, L-serine, L-tyrosine and L-valine can be used as sole nitrogen sources, but not L-alanine, glycine or xanthine. The diagnostic amino acid in the peptidoglycan is mesodiaminopimelic acid. Arabinose, galactose, glucose and ribose are present in whole-cell hydrolysates. Phospholipids are diphosphatidylglycerol, phosphatidylglycerol, phosphatidylmethylethanolamine, phosphatidylethanolamine, phosphatidylcholine, phosphatidylinositol, phosphatidylinositol mannosides and one unknown phospholipid. The predominant menaquinone is $\mathrm{MK}-9\left(\mathrm{H}_{4}\right)$. The major fatty acids $(>10 \%)$ are iso- $\mathrm{C}_{16: 0}$, anteiso- $\mathrm{C}_{17: 0}$, iso$\mathrm{C}_{15: 0}$ and iso- $\mathrm{C}_{17: 0}$.

The type strain, YIM $65359^{\mathrm{T}}\left(=\right.$ CCTCC AA $208062^{\mathrm{T}}=$ DSM $45269^{\mathrm{T}}$ ), was isolated from a surface-sterilized stem sample of Tripterygium hypoglaucum collected from Yunnan province, south-west China. The $\mathrm{G}+\mathrm{C}$ content of the genomic DNA of the type strain is $70.5 \mathrm{~mol} \%$.

\section{Acknowledgements}

This research was supported by the National Basic Research Program of China (No. 2004CB719601) and the Ministry of Science and Technology, P. R. China (2006DFA33550). W.-J. L. was also supported by the Program for New Century Excellent Talent in University (NCET).

\section{References}

Collins, M. D. \& Jones, D. (1980). Lipids in the classification and identification of coryneform bacteria containing peptidoglycans based on 2,4-diaminobutyric acid. J Appl Bacteriol 48, 459-470.

Collins, M. D., Pirouz, T., Goodfellow, M. \& Minnikin, D. E. (1977). Distribution of menaquinones in actinomycetes and corynebacteria. J Gen Microbiol 100, 221-230.

Embley, T. M., Wait, R., Dobson, G. \& Goodfellow, M. (1987). Fatty acid composition in the classification of Saccharopolyspora hirsuta. FEMS Microbiol Lett 41, 131-135.

Ezaki, T., Hashimoto, Y. \& Yabuuchi, E. (1989). Fluorometric deoxyribonucleic acid-deoxyribonucleic acid hybridization in microdilution wells as an alternative to membrane filter hybridization in which radioisotopes are used to determine genetic relatedness among bacterial strains. Int J Syst Bacteriol 39, 224-229.

Felsenstein, J. (1981). Evolutionary trees from DNA sequences: a maximum likelihood approach. J Mol Evol 17, 368-376.

Felsenstein, J. (1985). Confidence limits on phylogenies: an approach using the bootstrap. Evolution 39, 783-791.

Goodfellow, M., Lacey, J., Athalye, M., Embley, T. M. \& Bowen, T. (1989). Saccharopolyspora gregorii and Saccharopolyspora hordei: two new actinomycete species from fodder. J Gen Microbiol 135, 21252139.

Gordon, R. E., Barnett, D. A., Handerhan, J. E. \& Pang, C. H.-N. (1974). Nocardia coeliaca, Nocardia autotrophica, and the nocardin strain. Int J Syst Bacteriol 24, 54-63.

He, L., Li, W., Huang, Y., Wang, L. M., Liu, Z. H., Lanoot, B. J., Vancanneyt, M. \& Swings, J. (2005). Streptomyces jietaisiensis sp. nov., isolated from soil in northern China. Int J Syst Evol Microbiol 55, 1939-1944.

Kelly, K. L. (1964). Inter-Society Color Council - National Bureau of Standards Color Name Charts Illustrated with Centroid Colors. Washington, DC: US Government Printing Office.

Korn-Wendisch, F., Kempf, A., Grund, E., Kroppenstedt, R. M. \& Kutzner, H. J. (1989). Transfer of Faenia rectivirgula Kurup and Agre 1983 to the genus Saccharopolyspora Lacey and Goodfellow 1975, elevation of Saccharopolyspora hirsuta subsp. taberi Labeda 1987 to species level, and emended description of the genus Saccharopolyspora. Int J Syst Bacteriol 39, 430-441.

Lacey, J. \& Goodfellow, M. (1975). A novel actinomycete from sugar cane bagasse: Saccharopolyspora hirsuta gen. et sp. nov. J Gen Microbiol 88, 75-85.

Li, W. J., Xu, P., Schumann, P., Zhang, Y. Q., Pukall, R., Xu, L. H., Stackebrandt, E. \& Jiang, C. L. (2007). Georgenia ruanii sp. nov., a novel actinobacterium isolated from forest soil in Yunnan (China) and emended description of the genus Georgenia. Int J Syst Evol Microbiol 57, 1424-1428.

Li, J., Zhao, G. Z., Qin, S., Zhu, W. Y., Xu, L. H. \& Li, W. J. (2009). Streptomyces sedi sp. nov., isolated from a surface-sterilized tissue of Sedum sp. Int J Syst Evol Microbiol 59, 1492-1496.

Lu, Z., Liu, Z., Wang, L., Zhang, Y., Qi, W. \& Goodfellow, M. (2001). Saccharopolyspora flava sp. nov. and Saccharopolyspora thermophila sp. nov., novel actinomycetes from soil. Int J Syst Evol Microbiol 51, 319-325.

Mertz, F. P. \& Yao, R. C. (1990). Saccharopolyspora spinosa sp. nov. isolated from soil collected in a sugar mill rum still. Int J Syst Bacteriol 40, 34-39.

Mesbah, M., Premachandran, U. \& Whitman, W. B. (1989). Precise measurement of the $\mathrm{G}+\mathrm{C}$ content of deoxyribonucleic acid by high-performance liquid chromatography. Int J Syst Bacteriol 39, 159167.

Minnikin, D. E., Collins, M. D. \& Goodfellow, M. (1979). Fatty acid and polar lipid composition in the classification of Cellulomonas, Oerskovia and related taxa. J Appl Bacteriol 47, 87-95.

Qin, S., Li, J., Zhao, G. Z., Chen, H. H., Xu, L. H. \& Li, W. J. (2008). Saccharopolyspora endophytica sp. nov., an endophytic actinomycete isolated from the root of Maytenus austroyunnanensis. Syst Appl Microbiol 31, 352-357.

Saitou, N. \& Nei, M. (1987). The neighbor-joining method: a new method for reconstructing phylogenetic tree. Mol Biol Evol 4, 406425.

Sasser, M. (1990). Identification of bacteria by gas chromatography of cellular fatty acids. USFCC Newsl 20, 16.

Shirling, E. B. \& Gottlieb, D. (1966). Methods for characterization of Streptomyces species. Int J Syst Bacteriol 16, 313-340.

Smibert, R. M. \& Krieg, N. R. (1994). Phenotypic characterization. In Methods for General and Molecular Bacteriology, pp. 607-654. Edited by P. Gerhardt, R. G. E. Murray, W. A. Wood \& N. R. Krieg. Washington, DC: American Society for Microbiology.

Staneck, J. L. \& Roberts, G. D. (1974). Simplified approach to identification of aerobic actinomycetes by thin layer chromatography. Appl Microbiol 28, 226-231. 
Tamaoka, J., Katayama-Fujimura, Y. \& Kuraishi, H. (1983). Analysis of bacterial menaquinone mixtures by high performance liquid chromatography. J Appl Bacteriol 54, 31-36.

Tamura, K., Dudley, J., Nei, M. \& Kumar, S. (2007). MEGA4: Molecular Evolutionary Genetics Analysis (MEGA) software version 4.0. Mol Biol Evol 24, 1596-1599.
Thompson, J. D., Gibson, T. J., Plewniak, F., Jeanmougin, F. \& Higgins, D. G. (1997). The CLUSTAL_X windows interface: flexible strategies for multiple sequence alignment aided by quality analysis tools. Nucleic Acids Res 25, 4876-4882.

Waksman, S. A. (1961). The Actinomycetes, vol. 2. Baltimore: Williams \& Wilkins. 